PSYCHOLOGIA ROZWOJOWA, $2017 *$ tom 22, nr 1, s. 29-45

doi:10.4467/20843879PR.17.002.6416

www.ejournals.eu/Psychologia-Rozwojowa

KATARZYNA TOMASZEK

Uniwersytet Pedagogiczny im. KEN, Kraków

Pedagogical University of Cracow

e-mail: kat.tomaszek@gmail.com

\title{
Wielowymiarowość zaangażowania uczniów w aktywności szkolne
}

\section{Student School Engagement as a Multidimensional Construct}

\begin{abstract}
The article describes selected theoretical perspectives on student school engagement. School engagement is a meta-construct including a wide spectrum of mental attitudes such as: the sense of belonging to a school, acceptance of the goals of schooling, psychological investment in an effort directed toward learning, understanding, or mastering the knowledge, skills, or crafts that academic work is intended to promote, as well as emotional involvement with school, including the student's motivation to learn. Specific dimensions of student engagement were described as cognitive, affective and behavioral. School disengagement is a predictor of risk behavior, delinquency, proactive aggression, substance abuse, school drop-out syndrome and school burnout.
\end{abstract}

Keywords: student school engagement, development, education, academic achievement, disengagement.

Słowa kluczowe: zaangażowanie szkolne, rozwój, edukacja, osiągnięcia szkolne, brak zaangażowania.

\section{WPROWADZENIE}

Problematyka zaangażowania w różne aktywności, jakie podejmuje człowiek, wpisuje się w podejście określane terminem psychologia pozytywna. Badania prowadzone w tym nurcie mają na celu poszukiwanie takich zmiennych psychologicznych, które sprawiają, że człowiek doświadcza szczęścia, rozwija swoje cnoty i zalety, poszerza swoje zasoby, pokonuje trudności i potrafi je wykorzystać do samorozwoju (Gulla, Tucholska, 2007; Kwiatek,Wilczewska, 2015). Konstrukt ten odnosi się do przyjemności i pozytywnych emocji, jakie odczuwa jednostka, wykonując wybrane przez siebie działania, rozwiązując zadania, czy pełniąc funkcje społeczne i zawodowe. Początkowo teoretycy analizowali to zjawisko na gruncie psychologii organizacji, wskazując na większą efektywność i wyższą jakość pracy osób mocniej zaangażowanych. Obecnie zaangażowanie jest rozpatrywane również w kontekście środowiska społecznego (rodzina, rówieśnicy, społeczność lokalna i narodowa) oraz procesu edukacji (Appleton i in., 2008; Baker i in., 2003). Zjawisko to obejmuje swym zakresem działania człowieka (aspekt behawioralny), jego procesy poznawcze (aspekt kognitywny) i emocjonalne (aspekt afektywny) oraz jego relacje interpersonalne (aspekt społeczny/ relacyjny) (Archambault i in., 2013; Fredricks $i$ in., 2011; Havermans i in., 2014; Hazel i in., 2014). Coraz częściej teoretycy zaangażowania wskazują, że może ono stanowić swoistą postawę wartościującą jednostki (aspekt psychologiczny), a nawet określać światopogląd czy styl życia (aspekt wartościujący/duchowy) (Ramey $\mathrm{i}$ in., 2015; Wang, Peck, 2013). Inne określenia obecne w literaturze, a będące synonimami ana- 
lizowanego terminu to: poczucie przynależności do szkoły, poczucie więzi ze szkołą, poczucie przywiązania do szkoły (Fredricks i in., 2004; Libbey, 2004). Wzrost zainteresowania badaniami nad zaangażowaniem szkolnym wiąże się z faktem, że zmienna ta jest uznawana za ważny predykator sukcesów edukacyjnych i życiowych (Ouweneel i in., 2011). Helen Marks (2000) wskazuje, że wysokie zaangażowanie szkolne stanowi czynnik prorozwojowy, zwłaszcza w odniesieniu do funkcjonowania poznawczego i społecznego uczniów. Niski poziom zaangażowania szkolnego łączy się nie tylko ze słabym funkcjonowaniem dziecka w roli ucznia, a więc $\mathrm{z}$ trudnościami w nauce, brakiem zainteresowania przedmiotami, częstym wagarowaniem, alienacją szkolną, słabymi relacjami w środowisku szkolnym, ale także $\mathrm{z}$ syndromem rezygnacji $z$ dalszego kształcenia (Archambault i in., 2009; Fredricks i in., 2004; Veiga i in., 2014). Zgodnie z danymi UNESCO z 2013 roku około 14 milionów uczniów na świecie rezygnuje co roku z dalszego kształcenia (Awang-Hashim i in., 2015). W Islandii tylko połowa młodych ludzi kończy szkołę średnią, a we Włoszech, Szwecji, Norwegii i Nowej Zelandii jest to od 64 do $70 \%$ badanych (Wilson i in., 2011). Perspektywy zawodowe i życiowe uczniów rezygnujących z dalszej edukacji są niekorzystne. Znaczna część tych młodych ludzi pozostaje bez szans na zatrudnienie, ich status socjoekonomiczny jest niski (zmagają się z biedą), również ogólny stan zdrowia jest gorszy niż u osób kontynuujących naukę (Fredricks i in., 2011). Zasadność podejmowania tej problematyki potwierdzają też negatywne konsekwencje, jakie ma dla rozwoju dzieci i młodzieży brak zaangażowania szkolnego (Fall, Roberts, 2012; Pietarinen i in., 2014). Badania w grupie australijskich adolescentów pokazują, że co trzeci uczeń niezaangażowany w aktywności szkolne regularnie nadużywał substancji psychoaktywnych (nikotyna i narkotyki) (Aud i in., 2012). Uczniowie niezaangażowani częściej: naruszają reguły szkolne i prezentują zachowania problemowe, wagarują, angażują się w grupy dewiacyjne i mają konflikty z prawem, są sprawcami i ofiarami przemocy, podejmują ryzykowne kontakty seksualne (Ang i in., 2015; Dolzan i in., 2015). Istotne znaczenie badań i analiz teoretycznych nad tą zmienną potwierdza również skala zjawiska braku zaangażowania. Najbardziej zaangażowane w aktywność szkolną są dzieci ze szkół podstawowych, ale na każdym kolejnym etapie edukacji stopień zaangażowania spada i jest najniższy w szkołach średnich (Fredricks i in., 2011). Statystyki pokazują, że znaczna grupa uczniów doświadcza symptomów świadczących o niskim poziomie zaangażowania lub jego całkowitej utracie. W badaniach Gallup (2013) prowadzonych na grupie młodzieży 28\% uczniów wykazywało niskie zaangażowanie, a 17\% odznaczało się całkowitym brakiem angażowania się w aktywności szkolne. Bardziej aktualne wyniki badań, prowadzonych w USA na przełomie 2015 i 2016 roku, wskazują, że jedynie 44\% uczniów szkół średnich jest zaangażowanych w aktywności szkolne (Gallup, 2015-2016). Gregory Austin i Bonnie Benard (2007) podają, że ciągły brak zaangażowania cechuje od $40-60 \%$ adolescentów. $Z$ uwagi na powszechność zjawiska braku zaangażowania i jego negatywne konsekwencje prowadzenie badań nad czynnikami wzmacniającymi identyfikacje i uczestnictwo młodych ludzi w aktywnościach szkolnych wydaje się istotnym postulatem, zarówno w perspektywie edukacyjnej, jak i w kontekście rozwoju człowieka. Celem niniejszego artykułu jest stworzenie krytycznego przeglądu i integracja wiedzy teoretycznej, obejmującej strukturalne podejścia do zaangażowania uczniów w aktywności szkolne. $\mathrm{W}$ artykule zaprezentowane zostaną modele teoretyczne i definicje funkcjonujące w literaturze naukowej. Zarysowany powyżej zakres tematyczny pracy podyktowany jest przede wszystkim niewielką liczbą opracowań dotyczących problematyki zaangażowania szkolnego na gruncie polskim.

\section{Strukturalne podejścia do zaangażowania w aktywności szkolne}

Historia badań nad zaangażowaniem szkolnym jest stosunkowo krótka. Pierwsze artykuły podejmujące analizowaną problematykę pojawiły się w latach 80 . Przeprowadzony przez Ralpha Moshera i Bradforda MacGowana (1985) przegląd literatury ujawnił tylko dwie prace, 
w których pojawił się termin „zaangażowanie”. Tworzone w tym okresie definicje zaangażowania szkolnego uczniów były nieprecyzyjne i koncentrowały się tylko na aspekcie behawioralnym. W kolejnych latach zainteresowanie tym konstruktem stale rosło, a badacze zaczęli zauważać, że angażowanie się uczniów w środowisko szkolne nie tylko obejmuje zachowania, ale odnosi się także do osobistego stosunku jednostki do nabywania wiedzy i systemu edukacji. Wzrost badań nad tym zjawiskiem doprowadził do powstania wielowymiarowych modeli zaangażowania szkolnego, a zjawisko to zaczęto traktować jako metakonstrukt. James Appleton, Sandra Christenson oraz Michael Furlong (2008) zauważają, że chociaż zaangażowanie szkolne zyskiwało coraz większą popularność, to jednak brak było prac nad stworzeniem spójnej definicji i teorii go thumaczącej. Z tej przyczyny coraz cześciej krytykowano ten termin jako obejmujący swym zakresem zbyt wiele zmiennych, a przez to trudny do operacjonalizacji. Pojawily się również głosy, że wprowadzenie tego pojęcia do języka nauki jest zbędne, gdyż narusza regułę brzytwy Okhama. Zdaniem niektórych badaczy zmienna ta pod pewnymi względami odzwierciedla już istniejące w psychologii terminy, takie jak wewnętrzną motywację, przynależność, przywiązanie, samoaktualizację czy integrację (jako przeciwstawny kraniec wycofania) (Brophy, 1983; Macey, Schneider, 2008; Tucholska, 2012). W literaturze nadal brak jest jednoznacznej definicji ujmującej zaangażowanie szkolne. $\mathrm{W}$ dalszym ciągu nie wiadomo bowiem, czy zjawisko to odnosi się do zespołu zachowań, czy jest ono pewną dyspozycją jednostki (cecha osobowości), czy też stanem podlegającym dynamicznym zmianom $\mathrm{z}$ uwagi na działanie otoczenia (Szabowska-Walaszczyk, 2010). Niektórzy badacze definiują zaangażowanie przez pryzmat negatywnych konsekwencji pojawiających się w sytuacji jego braku, a zatem niezadowolenia z życia szkolnego, alienacji i oderwania odczuwanych w stosunku do szkoły (Connell, Wellborn, 1991; Skinner, Belmont, 1993). Znaczna część autorów, analizując to zjawisko, koncentruje się na czynnikach sprzyjających zaangażowaniu w naukę (Christenson, Anderson, 2002; Connell, Wellborn,
1991; Furlong i in., 2003). W płaszczyźnie psychologicznej zaangażowanie szkolne może być rozumiane jako suma fizycznej i psychicznej energii, którą uczeń czy student przeznacza na aktywności szkolne lub akademickie (Astin, 1984). Alexander Astin (1984) nie definiuje, czym jest energia w kontekście zaangażowania szkolnego. W artykule Valerie Russell, Mary Ainley oraz Eriki Frydenberg (2005) aspekt energetyczny zaangażowania odnosi się jednak do ilości wydatkowanej przez jednostkę energii na realizowane działanie, tzw. energy in action (jej wielkość wynika z relacji między osobą a aktywnością, którą ona podejmuje). Energia w kontekście edukacyjnym jest rozumiana jako wysiłek fizyczny związany z koncentracją na jak najlepszym wypełnieniu zadań szkolnych oraz nakład sił psychicznych (umysłowych) poświęcanych na zrozumienie materiału (a nie jedynie jego opanowanie) (O’Tool, Due, 2015). Zdaniem J. Appleton i współpracowników (2008) zjawisko to wiąże się z motywowaną wewnętrznie aktywnością i subiektywnymi odczuciami ucznia względem szkoły, dlatego najbardziej adekwatną nazwą jest zaangażowanie uczniów w aktywności szkolne. Poniżej zostaną opisane wybrane strukturalne ujęcia omawianego zagadnienia, które podzielono z uwagi na liczbę wyróżnianych przez autorów wymiarów. Zaznaczyć jednocześnie należy, że w literaturze przedmiotu istnieje wiele niejasności w tym aspekcie np. Ulrika Hallberg i Wilmar Schaufeli (2006) uznają, że zjawisko to może składać się z jednego lub trzech wymiarów. $Z$ tej przyczyny zaprezentowany podział obrazuje w zasadzie ewolucję poglądów na temat zaangażowania szkolnego. Jednocześnie ze względu na to, że część autorów opiera się jedynie na definicjach operacyjnych, sformułowanych dla potrzeb badań empirycznych, stworzony przegląd zawiera tylko wybrane definicje lub ogólne charakterystyki, przybliżające sposób ujmowania tego zjawiska od momentu pojawienia się tej problematyki w literaturze fachowej. 
Zaangażowanie szkolne rozumiane jako zespól zachowań polegających na efektywnym wypelnianiu zadań szkolnych przez ucznia - ujęcia jednowymiarowe

Pierwsze prace dotyczące zjawiska zaangażowania szkolnego prowadzono w nurcie edukacyjnym, a ich głównym celem było poszukiwanie zmiennych chroniących przed syndromem rezygnacji uczniów z dalszej edukacji (Skinner, Belmond, 1993). Zaangażowanie traktowano tu jako wskaźnik informujący o tym, że uczeń będzie kontynuował edukację. W tych ujęciach zwracano uwagę na postawę ucznia wobec obowiązków szkolnych, inicjatywę i aktywność oraz poszerzanie ról (Tucholska, 2012). Gary Natriello (1984), który jako jeden z pierwszych posłużył się terminem zaangażowanie w kontekście edukacyjnym, twierdził, że jest to stopień uczestnictwa ucznia w aktywnościach oferowanych w ramach programu szkolnego. Poziom zaangażowania odzwierciedlają prezentowane przez ucznia zachowania, a zatem stopień i częstość udziału w lekcjach, koncentracja na zadaniach, czas poświęcany na wykonanie zadania domowego i przygotowanie się do zajęć szkolnych, wysiłek wkładany w naukę (Brophy, 1983; Natriello, 1984). Zgodnie z tym podejściem zmienna ta rozciąga się na kontinuum, na którego końcu znajduje się brak zaangażowania, manifestowany m.in. przez nieuzasadnione absencje ucznia w szkole, oszukiwanie podczas sprawdzianów, apatię podczas lekcji, niszczenie mienia szkolnego. Jere Brophy (1983) określa ten kraniec jako wycofanie $\mathrm{z}$ aktywności szkolnych. Zdaniem tego autora zmienna ta jest wskaźnikiem wewnętrznej motywacji uczniów do pracy (głównie intelektualnej) na zajęciach (traktowanej tu jako dyspozycja) (Brophy, 1983). Według Gary’ego Natriella (1984) zaangażowanie szkolne determinowane jest przez wiele czynników, takich jak: cechy ucznia (w tym jego osobowość); politykę szkoły; środowisko szkolne; społeczność szkolną; opinie nauczycieli na temat ucznia. R. Mosher i B. MacGowan (1985) po analizie ówczesnej literatury zdefiniowali zaangażowanie jako stosunek do uczenia się oraz zachowania wskazujące na chęć uczestniczenia w realizacji programu szkolnego (pewien stan umysłu czy sposób zachowywania się). W zaproponowanym modelu wskazują na dwie grupy uwarunkowań: czynniki egzogenne (społeczne, ekonomiczne, środowiskowe i prawne normy oraz charakterystyki opisujące rodzinę ucznia) i endogenne (cechy ucznia).

\section{Zaangażowanie szkolne rozumiane jako dyspozycja ucznia do aktywnego uczestnictwa i identyfikacji ze szkołą - ujęcia dwuwymiarowe}

Dwuwymiarowe modele zaangażowania szkolnego odzwierciedlają potrzebę uwzględnienia w analizach psychologicznych aspektów aktywności uczniów, zwłaszcza elementu ich emocjonalnego ustosunkowania się do procesu nabywania wiedzy. Jeden z pierwszych modeli dwuwymiarowych został opracowany przez Jeremy'ego Finna (1989). Autor ten definiuje zaangażowanie uczniów jako stopień identyfikacji (poczucie przynależności do szkoły, uznawanie osiągnięć szkolnych za wartościowe i znaczące, tzw. wymiar emocjonalny) i uczestnictwa w życiu klasy i szkoły (wymiar behawioralny). Również Russel Rumberger i Katherine Larson (1998) wyróżniają dwa wymiary zaangażowania szkolnego, które decydują o stopniu adaptacji ucznia do systemu edukacji. Są to: wymiar społeczny (zachowania ucznia w szkole) oraz wymiar akademicki (postawa ucznia wobec szkoły i zdolności umożliwiające sprostanie wymaganiom stawianym przez nauczycieli). Jak pisze Fred Newmann (1992), chodzi nie tylko o wypełnianie $\mathrm{z}$ sukcesem obowiązków ucznia, ale także o dumę, jaka się pojawia, gdy uczeń opanuje jakiś obszar wiedzy, umiejętności czy rzemiosła. Zdaniem tego autora zaangażowanie to stopień, w jakim uczeń psychicznie inwestuje w uczenie się, a celem tej aktywności jest zrozumienie i poszerzenie swojej wiedzy. Tę wewnętrzną jakość odzwierciedlają: stopień koncentracji na nauce i wysiłek w nią wkładany. Praca nauczycieli nad wzmacnianiem zaangażowania szkolnego powinna obejmować dwa elementy: kształtowanie więzi ze szkołą (m.in. pozytywny klimat szkolny odznaczający się sprawiedliwością, wsparciem i opieką) i autentyczne uczenie (m.in. powiązane 
z realnymi problemami świata, wzmacniające wewnętrzną motywację do uczenia się i oparte na zabawie) (Newmann,1992). Na podstawie wyróżnionych przez R. Rumberger i K. Larson (1998) dwóch wymiarów zaangażowania szkolnego Hamish Coates (2007) stworzył typologię stylów zaangażowania uczniów w aktywności szkolne. Autor ten wyróżnił cztery style zaangażowania szkolnego: współpracujący, niezależny, intensywny, pasywny.

Wyróżnienie stylów zaangażowania szkolnego wskazuje, że uczniowie mogą się angażować w różne obszary życia szkolnego, a zmienna ta odzwierciedla nie tylko stopień koncentracji na nabywaniu wiedzy, ale także funkcjonowanie w środowisku szkolnym oraz stosunek do personelu pracującego w danej placówce. Szeroki zakres omawianego pojęcia wskazuje, że bada- nia nad zaangażowaniem szkolnym powinny obejmować również (a nawet przede wszystkim) subiektywne oceny dokonywane przez ucznia. W kontekście edukacyjnym uczeń może oceniać m.in. posiadane kompetencje, stopień kontroli nad otoczeniem (Co ja mogę zrobić?), możliwość realizacji preferowanych wartości i celów (Co ja chcę zrobić?) oraz poczucie więzi ze społecznością (Gdzie ja przynależę?) (National Research Council, Institute of Medicine, 2004, za: Appleton i in., 2008).

\section{Zaangażowanie szkolne jako psychologiczny stan - ujęcia wielowymiarowe}

W literaturze przedmiotu uznaje się, że pierwszą stricte psychologiczną definicję zaangażowa-

Rysunek 1. Style zaangażowania uczniów w aktywności szkolne według H. Coatesa (2007)

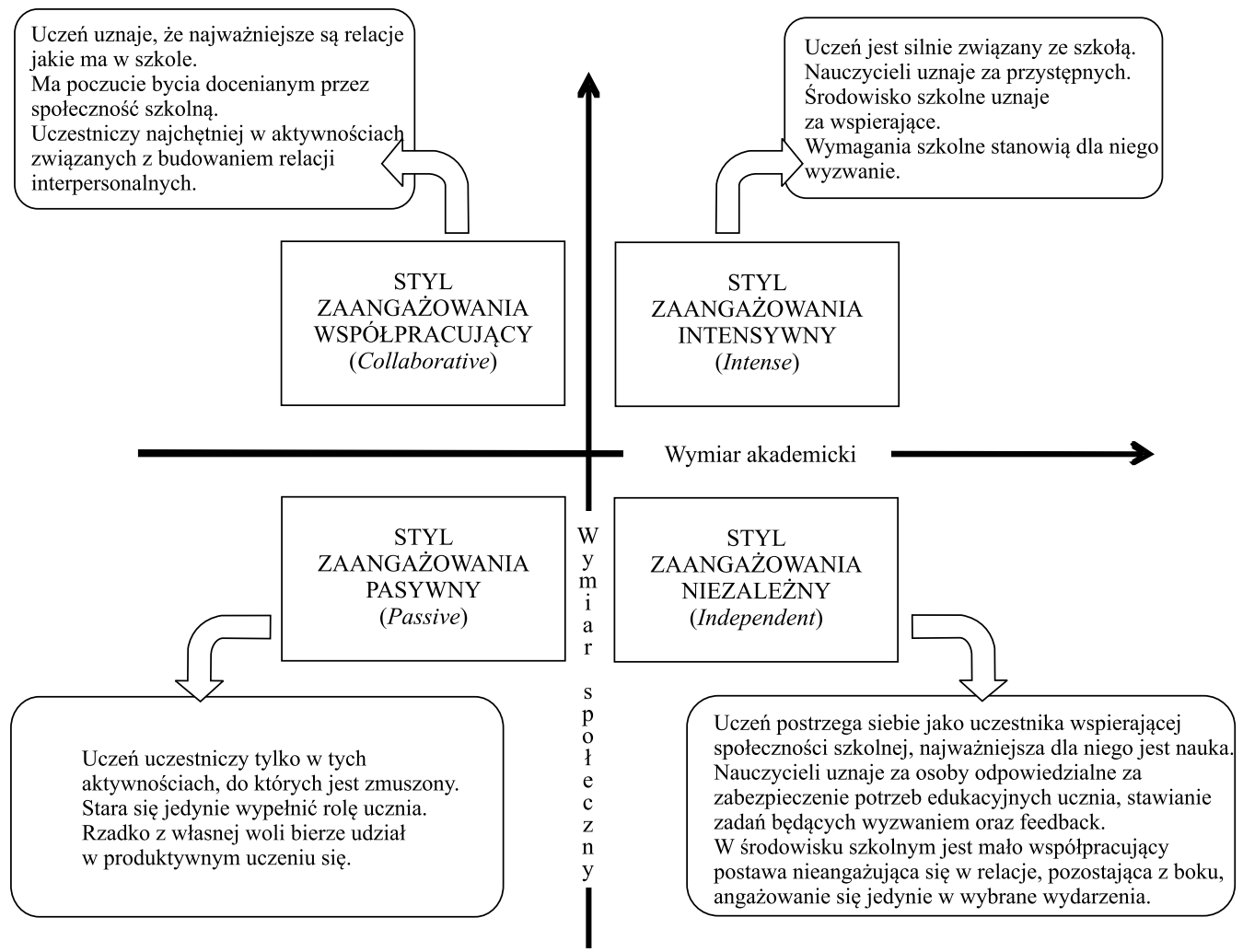

Źródło: opracowanie własne. 
nia zaproponował William Kahn (1990). Autor ten scharakteryzował to zjawisko w kontekście psychologii organizacji. W. Kahn (1990) zauważył, że osobista aktywność zawodowa pracowników może się przejawiać w trzech formach: fizycznej, poznawczej i emocjonalnej. Ten wielowymiarowy konstrukt obejmuje wdrażanie członków organizacji do pełnienia przez nich ról zawodowych. Im mocniejsze zaangażowanie jednostki, tym większa efektywność pracy, więcej pozytywnych osobistych relacji w organizacji i tym większe poczucie znaczenia wykonywanego zawodu. Taka perspektywa wydaje się wskazywać, że większe osobiste zaangażowanie w aktywność zawodową generuje włączanie elementów organizacyjnych w obraz siebie. William Macey i Benjamin Schneider (2008) podkreślają, że silnie zaangażowani pracownicy są zaabsorbowani i oddani swojej pracy; mają poczucie dumy, sensu i znaczenia w odniesieniu do odgrywanej roli zawodowej. Pracownicy ci odznaczają się ponadto poczuciem kompetencji, współdecydowania i wpływu (kontroli) na swoją pracę. W tym nurcie badań nad zaangażowaniem zmienna ta traktowana jest jako konstrukt negatywnie skorelowany z wypaleniem zawodowym (Kahn, 1990; Macey, Schneider, 2008; Schaufeli i in., 2002a). Autorzy definiują to zjawisko jako trwały i wszechobecny afektywno-motywacyjny stan umysłu, którego doświadcza osoba względem wykonywanej aktywności (Hallberg, Schaufeli, 2006; Schaufeli i in., 2002a). Zaangażowanie w tym ujęciu składa się z trzech wymiarów, takich jak: wigor (wysoki poziom energii wydatkowanej w pracy, wysiłek i wytrwałość oraz elastyczność działań - wymiar behawioralny), oddanie (wysoki poziom zaabsorbowania pracą, uczucia, a zatem entuzjazm, znaczenie, duma, inspiracja - wymiar emocjonalny) i zaabsorbowanie (silna koncentracja na pracy - wymiar poznawczy) (Schaufeli i in., 2002a). Osadzenie zaangażowania w szerszej perspektywie pozwoliło na bardziej uniwersalne zastosowania tego terminu i dało początek pracom nad zaangażowaniem w kontekście edukacyjnym. Wilmar Schaufeli, Marisa Salanova, Vincent González-Romá i Arnold Bakker (2002a) stworzyli narzędzie do badania tej zmiennej, tzw. UWES (Work
Engagement Utrecht Scale), które zostało readaptowane dla młodzieży uczącej się (Work Engagement Utrecht Scale-Student, UWES-S).Teoretycy zaangażowania zajmujący się tym zjawiskiem w kontekście edukacyjnym najczęściej proponują model trójczynnikowy, w którym wyróżnia się wymiary: behawioralny, emocjonalny i kognitywny (Fredricks i in., 2011). $Z$ tego powodu zostanie on w tym miejscu szerzej scharakteryzowany.

I. Wymiar behawioralny (inne określenia: Energia, Uczestnictwo) odzwierciedla intensywność angażowania się w obowiązki szkolne, wyrażaną przez: uczestnictwo w oferowanych zajęciach; wzmożony wysiłek w realizację zadań szkolnych; koncentrację na jak najlepszym wypełnianiu obowiązków wynikających z roli ucznia; wybór przedmiotów, które wymagają włożenia dużych nakładów pracy i stanowią dla ucznia wyzwanie. Swym zakresem obejmuje również wysoki poziom energii, wigoru, prężność i elastyczność przy opracowywaniu zadań umysłowych, wytrwałość, chęć uzyskiwania wysokich osiągnięć i rozwoju osobistego (Salmela-Aro $\mathrm{i}$ in., 2009; Salmela-Aro, Upadyaya, 2014). Zwraca się tu uwagę na pozytywne zachowania ucznia, które prowadzą do uzyskiwania przez niego sukcesów szkolnych oraz na dobre psychologiczne przystosowanie do wymagań środowiska szkolnego (Appleton i in., 2006; Fredricks i in., 2011; Tucholska, 2012).

Avi Assor, Haya Kaplan, Yaniv Kanat-Maymon oraz Guy Roth (2005) wyróżniają dwa style zaangażowania behawioralnego:

1) Zaangażowanie intensywne (intense engagement) w postaci dużego wysiłku ucznia wkładanego w realizację wymagań szkolnych oraz wytrwałość wykazywaną w odniesieniu do procesu nabywania wiedzy. Ten styl powiązany jest ujemnie z tzw. amotywacją (wycofanie, brak aktywności i intencji do działania), będącą formą obrony przed nadmiernie kontrolującą postawą nauczyciela postrzeganą jako zagrażającą autonomii ucznia.

2) Zaangażowanie ograniczone (częściowe) (restricted engagement) - wysiłek i wytrwałość występują jedynie w takim stopniu, 
Rysunek 2. Wymiary Zaangażowania Uczniów w Aktywności Szkolne

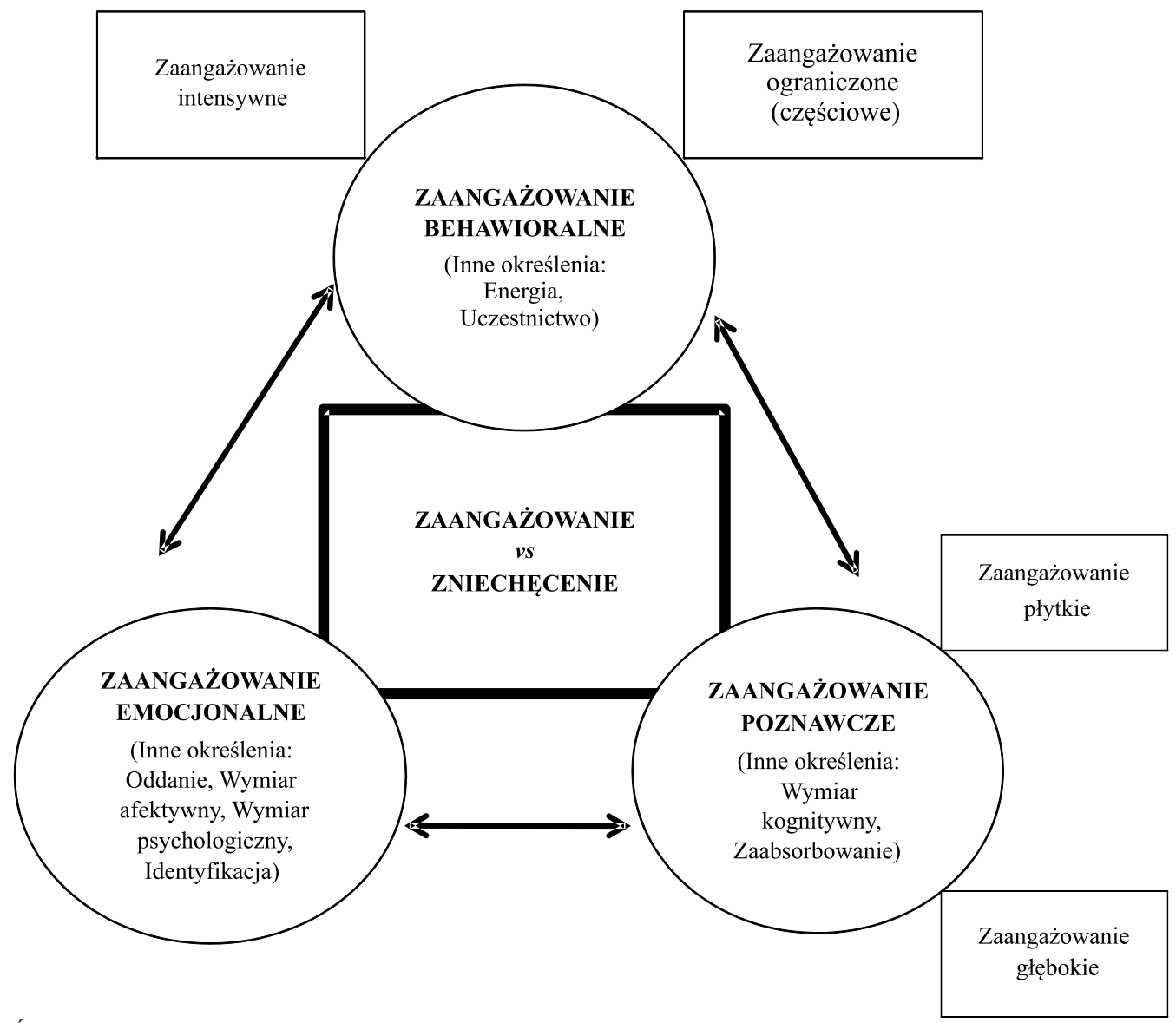

Źródło: opracowanie własne.

w jakim jest to konieczne, by uzyskać pozytywny stosunek nauczyciela i otrzymać pozytywną ocenę z przedmiotu. Ten styl jest powiązany z zewnętrzną motywacją do nauki.

II. Wymiar emocjonalny (inne określenia: Oddanie, Wymiar afektywny, Wymiar psychologiczny) dotyczy identyfikacji ze szkoła oraz pozytywnej emocjonalnej postawy wobec szkoły przejawiającej się: uznawaniem szkoły jako miejsca interesującego i wartościowego; zainteresowaniem zajęciami szkolnymi i odczuwaniem dumy z sukcesów szkolnych. Uczeń nie nudzi się na lekcjach, nie czuje niepokoju czy gniewu podczas zajęć, a w relacjach z kolegami i nauczycielami jest nastawiony na współpracę (Finn, 1989; Fredricks $i$ in., 2004; Wang $i$ in., 2015). Pozytywne emocje i entuzjazm odczuwane względem szkoły przyczyniają się do efektywnego realizowania długoterminowych celów, a więc ukończenia szkoły czy studiów (Salmela-Aro i in., 2009; Salmela-Aro, Upadyaya, 2014; Tucholska, 2012). Uczniowie mocno zaangażowani mają poczucie przynależności do szkoły (poczucie bycia znaczącą częścią całej społeczności szkolnej). Środowisko szkolne postrzegane jest jako znaczące, interesujące i wartościowe (Wang, Peck, 2013). 
III. Wymiar poznawczy (Wymiar kognitywny, Zaabsorbowanie) dotyczy umiejętności rozwiązywania pojawiających się problemów przez stosowanie metapoznawczych strategii. Wskazuje się tu też na rozwagę, troskę i gotowość do inwestowania swoich sił i czasu, by przyswoić materiał oraz nabyć umiejętności (Tucholska, 2012). Poziom tej zmiennej odzwierciedla stopień, w jakim uczeń inwestuje w naukę, a więc w jakim stopniu poszukuje racjonalnych i efektywnych strategii uczenia się; w jakim stopniu może zrezygnować $\mathrm{z}$ innych aktywności na rzecz uczenia się oraz jak mocno koncentruje się na nauce jako swoistym celu życiowym (Salmela-Aro, Upadyaya, 2012). Głównym jej przejawem jest zdolność do samoregulacji. Uczeń mocno zaangażowany jest tak mocno ,zaabsorbowany” nauką, że nie może się oderwać od tej czynności (Schaufeli i in., 2002b). Wymiar poznawczy wiąże się z wewnętrzną motywacją do nauki i traktowaniem czynności nabywania wiedzy jako wartości ,samej w sobie” (Fredricks i in., 2004). Pomiar tego wymiaru opiera się na trzech aspektach: (1) subiektywne postrzeganie własnego zaangażowania poznawczego; (2) szacowany przez ucznia wysiłek i wytrwałość w realizacji obowiązków szkolnych; (3) stopień zaabsorbowania wykonywanymi przez ucznia czynnościami (Tucholska, 2012). Whitney Smiley i Robin Anderson (2011) wyróżniają tu dodatkowo dwa poziomy: płytkie i głębokie zaabsorbowanie nabywaniem wiedzy. Na pierwszym poziomie zachowania ucznia obejmują strategie zapamiętywania i swoiste rytuały (nawyki) uczenia się, które umożliwiają opanowanie podstawowej wiedzy z tego zakresu i uzyskanie pozytywnej oceny. Drugi poziom wiąże się z zarządzaniem własnymi zasobami i inwestowaniem ich w naukę, a celem tych działań jest opanowanie materiału na poziomie eksperckim.

Wyniki empirycznych analiz prowadzonych w 12 krajach: Austria, Kanada, Chiny, Cypr, Estonia, Grecja, Malta, Portugalia, Rumunia, Korea Południowa, Wielka Brytania i Stany Zjednoczone na grupie 3.420 uczniów potwierdziły trójczynnikową strukturę tej zmiennej (Lam i in., 2014). W literaturze wskazuje się, że każdy z wyłonionych wymiarów zaangażowania może być badany osobno z różnych perspektyw:
- ucznia, który dokonuje samoopisu na temat swojego funkcjonowania w szkole (m.in. Skala Zaangażowania Szkolnego (SES) Appletona i współpracowników; Skala Motywacji i Zaangażowania MES autorstwa Andrew Martina; Skala do pomiaru Zaangażowania SEM MacArthura; Skala do badania zaangażowania szkolnego młodzieży licealnej HSSSE; Skala Identyfikacji ze szkołą Finn);

- opinii nauczyciela na temat ucznia (Skala Zaangażowanie vs Niezadowolenia EvsD Skinner, Indeks Zaangażowania w aktywność czytania REI Wigfield i Guthrie);

- obserwatora, który raportuje obserwowalne zachowania ucznia podczas lekcji (Zachowania uczniów w szkole BOSS Shapiro; Zachowania w klasie AIMS Roehrig) (Fredricks i in., 2011).

Warto dodać, że według Isabelle Archambault, Michela Janosz, Jean-Sebastiena Fallu oraz Lindy Pagani (2009) wymiar behawioralny w największym stopniu pozwala na predykcję osiągnięć szkolnych oraz syndromu rezygnacji $\mathrm{z}$ dalszej nauki. Autorzy proponują, by pomiar zaangażowania opierał się na tym wymiarze, a samo zjawisko określają jako Zaangażowanie w środowisko klasowe (Classroom Engagement). Według Isabelle Archambault, Lindy Pagani oraz Caroline Fitzpatrick (2013) behawioralny aspekt zaangażowania stanowi ponadto dobry wskaźnik poziomu pozostałych wymiarów.

Należy zauważyć, że zarówno struktura, ilość, jak i przeciwstawne bieguny wymiarów opisujących zaangażowanie w kontekście edukacyjnym są nadal kwestią dyskusyjną. Zdaniem niektórych autorów, np. Sandry Christenson i Amy Anderson (2002), zaangażowanie tworzą cztery wymiary: wymiar psychologiczny (przynależność), wymiar behawioralny (uczestnictwo), wymiar kognitywny (uczenie oparte na samoregulacji), wymiar akademicki (czas na wykonanie zadania). Według Johnmarshalla Reeve i Ching-Mei Tseng (2011) czwarty wymiar budujący zaangażowanie to Sprawczość (Agency) rozumiana jako konstruktywny i osobisty wkład w realizowane zadania szkolne. Uczeń intencjonalnie w sposób proaktywny nadaje 
osobiste znaczenie (personalizuje) treściom, których się uczy, oraz warunkom i okolicznościom, w których nabywa wiedzę. W wymiarze zaangażowania uwidacznia się istotny wkład ucznia w kształt zajęć dotyczących interesującego go tematu, a zatem uczeń samodzielnie stawia pytania, określa swoje preferencje, daje sugestie, dzieli się swoimi opiniami (co mu się podobało, a co nie), mówi o osobistych przeżyciach odnoszących się do interesującego go tematu, o swoich przemyśleniach i potrzebach z tym związanych; informuje o potrzebie szerszego omówienia zagadnienia, zabiega o informację dotyczącą źródel, z których sam mógłby skorzystać, by zgłębić wiedzę; samodzielnie poszukuje dróg rozwiązania jakiegoś problemu, innych sposobów ukazania zagadnienia; zwraca się z prośbą do nauczyciela o tutoring, feedbeck, czy o konkretne przykłady, by łatwiej mógł zrozumieć abstrakcyjną teorię, która go interesuje; prosi o pomoc w lepszym poznaniu zjawiska. Istnienie tego wymiaru zaangażowania ucznia w aktywność szkolną potwierdzają najnowsze badania walidacyjne Feliciano Veiga (2016) nad skalą SES-4DS. Brak jednoznacznej i spójnej teorii zaangażowania widoczny jest również w wyodrębnianiu przez różnych autorów innych subtypów czy form tego zjawiska. Według Cynthii Hazel, Emmy Vazirabadi oraz Johna Gallaghera (2013) zaangażowanie ucznia w aktywność szkolną składa się z takich elementów strukturalnych, jak: aspiracje, przynależność oraz produktywność. Heather Ramey, Linda Rose-Krasnor, Michael Busseri, Shannon Gadbois, Anne Bowker oraz Leanne Findlay (2015) wskazują, że psychologiczne zaangażowanie oprócz wymiaru kognitywnego i afektywnego powinno obejmować wymiar duchowy (relacyjny). Zasadność takiego podziału wynika z tego, że jednostka, angażując się w jakąs aktywność, przekracza własne ograniczenia. Wymiar duchowy został ujawniony jako ważny element zaangażowania $\mathrm{w}$ badaniach dzieci i młodzieży. Linda Benavides (2014) definiuje go jako poszukiwanie znaczenia, celów, więzi, wewnętrznego pokoju i autotranscendecji. Kwestią problematyczną pozostaje nadal terminologia stosowana do określenia braku zaangażowania uczniów w aktywności szkolne. Najczęściej autorzy posiłkują się pojęciem niezadowolenie/zniechęcenie/zrażenie się do czegoś (disaffection) (Connell, Wellborn, 1991; Skinner i in., 1993), ale w literaturze pojawiają się również takie terminy, jak: poczucie alienacji, odłączenie, wycofanie i oderwanie (Fredricks i in., 2004); doświadczanie wypalenia szkolnego/akademickiego (Schaufeli i in., 2002b). W tym kontekście ciekawe wydaje się rozróżnienie zaproponowane przez Vicki Trowler (2010). Autorka wskazuje na istnienie trzech biegunów zaangażowania: pozytywne zaangażowanie, negatywne zaangażowanie oraz brak zaangażowania.

Powyższe rozróżnienie sugeruje, że pomiar jedynie krańców kontinuum zaangażowanie $v s$ zniechęcenie jest niewystarczający do określenia poziomu tej zmiennej. Koncentracja tylko na identyfikacji wymiarów zaangażowania, miała jeszcze jedną istotną wadę, nie pozwalała na jednoznaczne odróżnienie perspektywy subiektywnych doznań od obiektywnych wskaźników. $\mathrm{Na}$ aspekt obiektywnego i subiektywnego pomiaru zaangażowania szkolnego pośrednio zwrócili uwagę J. Appleton i współpracownicy (2008), wyróżniając wymiary obserwowalne (wymiar akademicki i behawioralny) i interioryzowane (wymiar psychologiczny i kognitywny).

Zasadniczo strukturalne podejścia do zaangażowania szkolnego pozwoliły na określenie wymiarów tego zjawiska. Powyższe wyróżnienie dało początek znacznej liczbie badań nad poziomem zaangażowania szkolnego i akademickiego w grupie dzieci, młodzieży i studentów. Określenie struktury zaangażowania szkolnego umożliwiło ponadto poszerzenie obszaru badań empirycznych o poszukiwanie zmiennych osobowościowych i środowiskowych, stanowiących jego korelaty i predykatory. Niewątpliwą wadą zaprezentowanych powyżej ujęć była marginalizacja kwestii mechanizmów odpowiedzialnych za wzmacnianie lub spadek poziomu zaangażowania. Koncentracja na identyfikacji wymiarów zaangażowania nie obejmowała w zasadzie ustalenia spójnej definicji tego konstruktu. W. Schaufeli i współpracownicy (2002a) w swej koncepcji zaangażowania w pracę odróżniają stan chwilowy i konkretny od bardziej trwałego i wszechobecnego stanu 
Tabela 1. Bieguny zaangażowania według V. Trowler

\begin{tabular}{|l|l|l|l|}
\hline & $\begin{array}{c}\text { Pozytywne zaangażo- } \\
\text { wanie }\end{array}$ & Brak zaangażowania & $\begin{array}{l}\text { Negatywne zaangażo- } \\
\text { wanie }\end{array}$ \\
\hline $\begin{array}{l}\text { Wymiar behawio- } \\
\text { ralny }\end{array}$ & $\begin{array}{l}\text { Obecność na zajęciach, } \\
\text { uczestniczenie z entu- } \\
\text { zjazmem w lekcjach }\end{array}$ & $\begin{array}{l}\text { Opuszczanie zajęć bez } \\
\text { podania przyczyn }\end{array}$ & $\begin{array}{l}\text { Bojkotowanie, pikieto- } \\
\text { wanie, przeszkadzanie } \\
\text { w zajęciach }\end{array}$ \\
\hline Wymiar emocjonalny & Zainteresowanie & Nuda & Odrzucenie, odmowa \\
\hline Wymiar kognitywny & $\begin{array}{l}\text { Zadania, które są wy- } \\
\text { magane przez nauczy- } \\
\text { ciela, uczeń chętnie } \\
\text { wykonuje i samodziel- } \\
\text { nie poszerza zakres } \\
\text { wymaganej wiedzy }\end{array}$ & $\begin{array}{l}\text { Spóźnianie się z wy- } \\
\text { pełnianiem obowiąz- } \\
\text { ków szkolnych, } \\
\text { realizacja zadań w po- } \\
\text { śpiechu lub wcale }\end{array}$ & $\begin{array}{l}\text { Redefiniowanie kry- } \\
\text { teriów zadań, które } \\
\text { nauczyciel stawia ucz- } \\
\text { niowi }\end{array}$ \\
\hline
\end{tabular}

Źródło: opracowanie na podstawie Trowler, 2010, s. 6.

uczuciowo-poznawczego. W większości zaprezentowanych podejść strukturalnych nie określono tej najważniejszej kwestii dla pomiaru zaangażowania szkolnego. Choć należy dodać, że niektórzy autorzy wskazywali tu na kontekstualny wpływ takich czynników, jak jakość środowiska rodzinnego, rówieśniczego i szkolnego na poziom tej zmiennej (m.in. Christenson, Anderson, 2002; Fredricks i in., 2004). Według Cynthii Hazel, Emmy Vazirabadi, Jennifer Albanes oraz Johna Gallaghera (2014) zaangażowanie szkolne powinno się rozpatrywać w kategoriach stopnia dopasowania między uczniem a środowiskiem szkolnym. Podkreśla się, że stan ten można zmieniać (modelować) i powinno ujmować się go jako zmienną transakcyjną i podlegającą fluktuacji (Hazel i in., 2013). Podobnie jak zaangażowanie w aktywność zawodową, tak też zaangażowanie szkolne podlega dynamicznym zmianom w trakcie rozwoju jednostki (Fredricks i in., 2004). Również Andrew Martin, Brad Papworth, Paul Ginns, Lars-Erik Malmberg, Rebecca Collie, Rafael Calvo (2015) podkreślają, że na zjawisko to nie można patrzeć jedynie z perspektywy cechy, która pozostaje na tym samym poziomie. Rezultaty badań pokazują, że poziom zaangażowania różni się w zależności od etapu edukacyjnego, na którym jest uczeń. Dzieci w wieku 6-11 lat cechują się znacznie wyższym poziomem zaangażowania niż młodzież (Tucholska,
2012). Jednocześnie, chociaż teoretycy i badacze zaangażowania wskazują na konieczność spojrzenia na tę zmienną jako na pewien proces podlegający zmianom, to postulat ten nie został dotychczas ujęty w formie spójnej koncepcji teoretycznej. Pojawia się raczej jako założenie w części badań empirycznych. Zaangażowanie szkolne traktowane jest tu jako psychologiczny proces będący mediatorem między kontekstowymi czynnikami środowiska szkolnego, kreującymi klimat społeczny (tj. struktura klasy, relacje interpersonalne klasa-nauczyciel oraz uczeń-uczeń) i wpływającymi na osiągnięcia szkolne (Lam i in., 2014). Wartość tej zmiennej może wzrastać lub się zmniejszać w zależności od czynników sytuacyjnych, np. jakości nauczania, stopnia trudności stawianych uczniowi zadań, poziomu autonomii uczniów, na jaki nauczyciel zezwala, zbieżności zainteresowań ucznia z programem nauczania (Reeve, Tsen, 2011; Skinner i in., 2008). A. Martin i współpracownicy (2015) w swoich badaniach nad zaangażowaniem i motywacją uwzględniają fluktuację poziomu zaangażowania ucznia w kilku przedziałach czasowych: (a) w ciągu dnia, (b) w ciągu tygodnia, (c) w miesiącu, oraz (d) różnice między trzema perspektywami czasowymi u danej osoby. Wyniki tych badań wskazują, że dla zwiększenia zaangażowania i motywacji do nauki istotne znaczenie mają kontakty twarzą w twarz w ciągu dnia oraz czynniki jednostkowe 
Tabela 2. Model spektrum poziomów zaangażowania vs oderwania młodzieży w ujęciu J. Burns i współpracowników

\begin{tabular}{|c|c|}
\hline $\begin{array}{l}\text { Brak zaangażowania } \\
\text { (odłączenie, oderwanie) } \\
\text { (Disengaged) }\end{array}$ & $\begin{array}{l}\text { Doświadczanie przez ucznia poczucia alienacji, oderwania od wartości, } \\
\text { braku znaczenia własnych działań. Uczeń odczuwa niedostatek wiedzy } \\
\text { i umiejętności. Otoczenie nadaje mu etykietę osoby mało zdolnej. } \\
\text { Czynniki ryzyka: strukturalne bariery w instytucji, takie jak: niespra- } \\
\text { wiedliwość, ograniczenie zasobów i możliwości rozwoju. }\end{array}$ \\
\hline $\begin{array}{l}\text { Ryzyko utraty zaanga- } \\
\text { żowania } \\
\text { (Engaged with Risk) }\end{array}$ & $\begin{array}{l}\text { Uczeń jest zaangażowany w aktywności szkolne, prezentuje jednak za- } \\
\text { chowania ryzykowne, które narażają go na utratę zaangażowania np. } \\
\text { przynależność do gangów młodzieżowych, w których dochodzi do aktów } \\
\text { przemocy, nadużywanie substancji psychoaktywnych (narkotyki i alko- } \\
\text { hol). } \\
\text { Czynniki ryzyka: zachowania ryzykowne, wykluczenie społeczne przez } \\
\text { grupy pozytywne - podporządkowane regułom społecznym. }\end{array}$ \\
\hline $\begin{array}{l}\text { Zaangażowanie na ni- } \\
\text { skim poziomie (poniżej } \\
\text { oczekiwanego poziomu) } \\
\text { (Under-Engaged) }\end{array}$ & $\begin{array}{l}\text { Uczeń ceni aktywności szkolne i chce zwiększyć swoje uczestnictwo } \\
\text { w nich, ale napotyka na bariery: polityczne, socjoekonomiczne, kulturo- } \\
\text { we itp. } \\
\text { Czynnik ryzyka: utrudniony dostęp do zasobów i alternatywnych ścieżek } \\
\text { rozwoju. }\end{array}$ \\
\hline $\begin{array}{l}\text { Zaangażowanie } \\
\text { (Engaged Youth) }\end{array}$ & $\begin{array}{l}\text { Uczeń jest zaangażowany w aktywności szkolne, co implikuje kreatyw- } \\
\text { ność i pozytywne emocje związane z instytucją szkolną. Struktura insty- } \\
\text { tucji w sposób formalny i nieformalny wzmacnia zaangażowanie. } \\
\text { Czynniki generujące: dostęp do zasobów, wsparcie środowiska rodzinne- } \\
\text { go, rówieśniczego i szkolnego, wspieranie autonomii ucznia. }\end{array}$ \\
\hline $\begin{array}{l}\text { Wysoki poziom zaanga- } \\
\text { żowania } \\
\text { (Highly Engaged) }\end{array}$ & $\begin{array}{l}\text { Uczeń przejawia silne zaangażowanie, inwestuje swoje zasoby i zdolno- } \\
\text { ści, by realizować w konwencjonalny sposób cele instytucji, które uznaje } \\
\text { za wartościowe i zbieżne z własnymi. Uczeń aktywnie uczestniczy w ży- } \\
\text { ciu szkoły. Uczeń uznawany jest w swoim środowisku za eksperta i po- } \\
\text { trafi dzielić się swą wiedzą z innymi. } \\
\text { Czynniki generujące: dostęp do środków ekonomicznych, edukacji oraz } \\
\text { kulturowych zasobów, wsparcie środowiska rodzinnego, rówieśniczego } \\
\text { i szkolnego, wspieranie autonomii ucznia. }\end{array}$ \\
\hline $\begin{array}{l}\text { Nadmierny poziom za- } \\
\text { angażowania } \\
\text { (Over-Engaged })\end{array}$ & $\begin{array}{l}\text { Uczeń prezentuje wysoki poziom oddania i koncentracji na podejmowa- } \\
\text { nych działaniach; otoczenie uznaje go za eksperta i osobę bardzo zdol- } \\
\text { ną. Z tego powodu uczniowi stawiane są bardzo wysokie wymagania } \\
\text { - środowisko rodzinne, rówieśnicze i szkolne oczekuje od niego samych } \\
\text { sukcesów. } \\
\text { Czynnik ryzyka: nadmierne wymagania ze strony otoczenia społecznego } \\
\text { i instytucji, co wiąże się z przeżywaniem silnych napięć i dystresu gene- } \\
\text { rujące wypalenie szkolne (przeciążenie obowiązkami i wyczerpanie sił). }\end{array}$ \\
\hline
\end{tabular}

Źródło: opracowanie własne na podstawie Burns i współpracowników (2008, s. 13-14).

(cechy studenta). Według Jane Burns, Philippy Collin, Michelle Blanchard, Natashy De-Freitas i Sian Lloyd (2008) na różnych etapach edukacji uczeń oscyluje między postawą osoby mocno zaangażowanej a postawą wskazującą na oderwanie (brak zaangażowania). Ten proces może dotyczyć wszystkich obszarów funkcjonowania ucznia albo też tylko niektórych elementów środowiska, np. szkoły, relacji rówieśniczych czy rodzinnych.

Zaprezentowane powyżej kontinuum poziomów zaangażowania ucznia zwraca uwagę na jeszcze jedną kwestię, zasadniczo nieobecną w ujęciach strukturalnych. Maksymalne nasilenie 
w poszczególnych komponentach zaangażowania jest zjawiskiem nieadaptacyjnym i utrudniającym rozwój (Burns i in., 2008; Martin i in., 2010). Mocne zaangażowanie w powiązaniu z presją otoczenia, by sprostać rosnącym wymaganiom, stanowi istotny czynnik stresogenny (Tomaszek, 2015). Uczniowie $\mathrm{z}$ tej grupy są narażeni na przeciążenie obowiązkami szkolnymi i przeżywanie syndromu wypalenia szkolnego (Salmela-Aro, Upadyaya, 2014).

\section{Synteza podejść strukturalnych w modelu zaangażowania uczniów $w$ aktywności szkolne autorstwa J. Appleton, S. Christenson i M. Furlong}

Analiza funkcjonujących w literaturze ujęć teoretycznych i wyników badań dokonana przez J. Appleton i współpracowników (2008) pozwoliła na stworzenie całościowego modelu zaangażowania. Autorzy przyjmują za Jamesem Connell i Jamesem Wellborn (1991), że jeśli psychologiczne potrzeby autonomii, przynależności i kompetencji są zgodne z wymaganiami kulturowymi stawianymi przez środowisko rodzinne, szkolne i zawodowe, pojawia się zaangażowanie w aspekcie afektywnym, behawioralnym oraz kognitywnym. W sytuacji braku takiej zgodności występuje niezadowolenie. W modelu zaangażowanie ucznia jest swoistym mediatorem między kontekstualnymi czynnikami (facylitatory) a pożądanymi wynikami w nauce. J. Appleton i współpracownicy (2008) uznają, że wymiary zaangażowania odpowiadają za stopień odczuwanej więzi ze szkołą i osiągnięcia szkolne. Czynniki facylitujące siłę przywiązania to: odpowiednie praktyki dyscyplinujące uczniów, właściwy nadzór rodziców w zakresie odrabiania zadań domowych oraz pozytywny stosunek rówieśników do obowiązków szkolnych (akademickich). Warto dodać, że facylitująca rola klimatu klasowego i stylu nauczania w zaangażowaniu została potwierdzona w badaniach Dewey Cornell, Kathana Shukla i Timothy'ego Konold (2016). W świetle tych danych wsparcie okazywane w klasie, autorytatywny klimat i sprawiedliwość w dyscyplinowaniu uczniów są czynnikami wzmacniającymi zaangażowanie, sprzyjającymi wysokim osiągnięciom szkol- nym i aspiracjom edukacyjnym. Wydaje się, że zaprezentowany model stosunkowo dobrze ujmuje kontekstualne aspekty zaangażowania, ściśle związane ze sferą funkcjonowania określaną przez Urie Bronfenbrennera (1993) jako mikrosfera (rodzina i klasa). Warto zauważyć, że zdaniem takich autorów jak Urie Bronnfenbrener i Pamela Morris (2006), to właśnie pozytywne i bliskie stosunki emocjonalne, tzw. relacje twarzą w twarz na poziomie mikrosystemu (rodziny czy klasy) są decydujące dla prawidłowego rozwoju dziecka. W świetle badań wsparcie otrzymywane od rodziców i nauczycieli stanowi silniejszy predykator zaangażowania szkolnego niż wsparcie uzyskiwane od rówieśników (Fernández-Zabala i in., 2015). Problemy związane z relacjami interpersonalnymi w środowisku szkolnym wydają się dodatkowym czynnikiem ryzyka utraty zaangażowania szkolnego.

Kwestią nieuwzględnioną w modelu są czynniki kulturowe wpływające istotnie na stosunek ucznia do systemu edukacji. Ten aspekt podkreślają J. Burns i współpracownicy (2008), wskazując na rolę takich aspektów, jak: dyskryminacja (z uwagi na status socjoekonomiczny, rasę, płeć, narodowość, fizyczną lub psychiczną niepełnosprawność), niska dostępność dóbr ze względu na znaczną odległość od centrów kulturowych, ograniczony dostęp do służb pomocowych, słabe relacje społeczne w wymiarze lokalnym, ograniczone alternatywy wyboru drogi życiowej (możliwości rozwoju). Model nie zawiera również odniesień do tak istotnego obecnie wpływu mediów oraz nowoczesnych technologii informacyjnych na funkcjonowanie szkolne dzieci i młodzieży. Ponadto nie uwzględniono w nim obszarów, względem których uczeń może odczuwać zaangażowanie, a więc procesu uczenia się, projektowania własnych zajęć edukacyjnych, e-learningu, pozalekcyjnych zajęć edukacyjnych, społeczności szkolnej, aktywności prospołecznej i samorządowej w środowisku szkolnym. Model nie pozwala również na odróżnienie od siebie motywacji uczniów zaangażowanych w aktywności szkolne: motywacji wewnętrznej, amotywacji, motywacji zewnętrznej i jej rodzajów. 
Rysunek 3. Model zaangażowania ucznia w aktywności szkolne
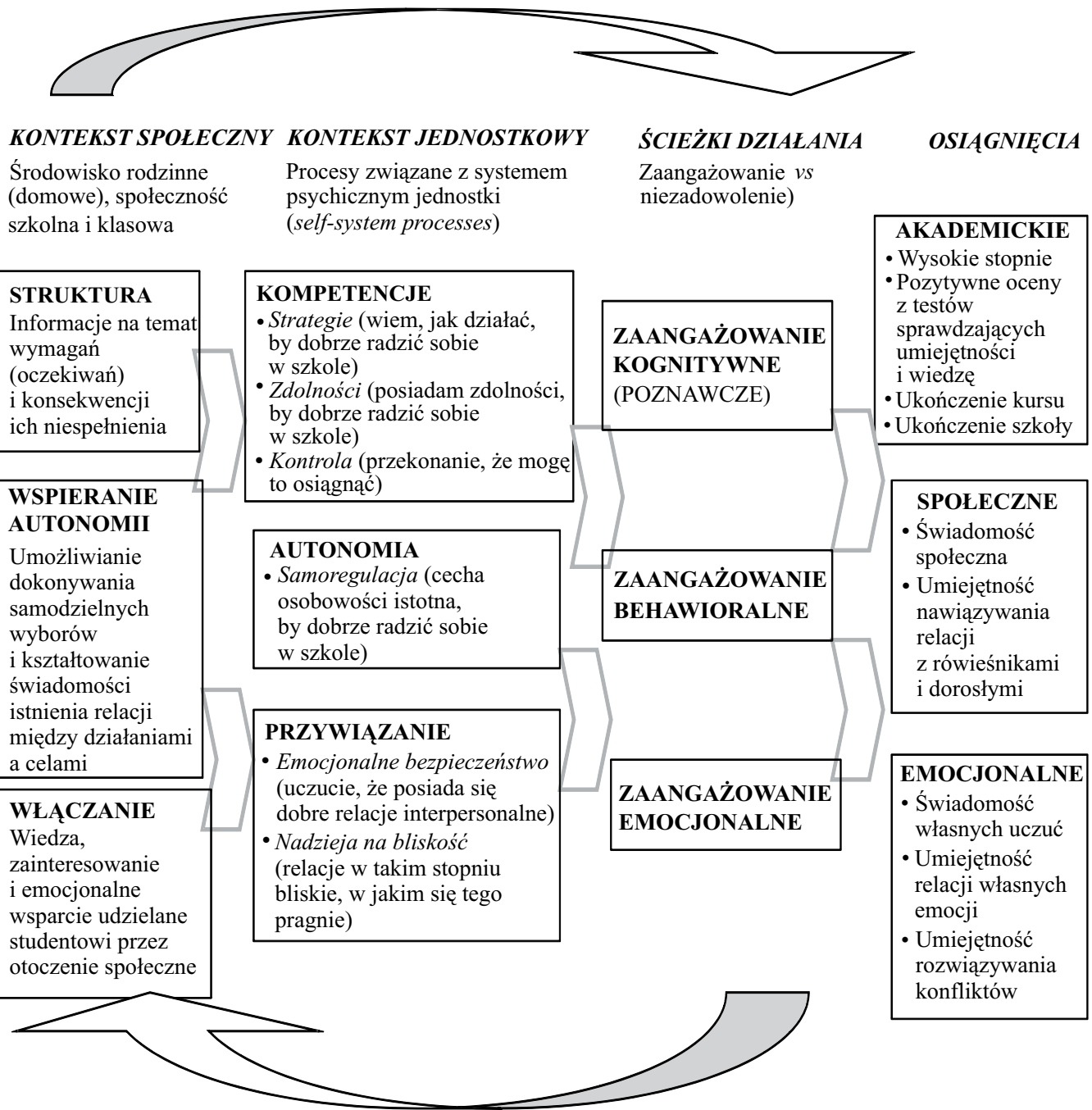

Źródło: J. Appleton i współpracownicy (2008, s. 12).

\section{PODSUMOWANIE}

Zaprezentowane ujęcia zaangażowania uczniów w aktywność szkolną wskazują, że zjawisko to jest metakonstruktem, składającym się z wielu wymiarów. Odzwierciedla ono zarówno zinterioryzowane, jak i uzewnętrzniane odczucia ucznia, jego wysiłek włożony w nabywanie wiedzy w szkole oraz stopień jego adaptacji do środowiska szkolnego. Jest to zjawisko biopsychospołeczne, którego poziom ściśle wiąże się $\mathrm{z}$ jakością środowisk, w których funkcjonuje uczeń. Zaangażowanie ucznia w aktywności szkolne podlega dynamicznym zmianom w toku rozwoju jednostkowego i społecznego. Ujęcia strukturalne, choć nie do końca spójne, zapoczątkowały wiele wartościowych pod względem aplikacyjnym badań. Zaprezentowany przegląd 
podejść teoretycznych ma na celu wskazanie, że zaangażowanie szkolne lub jego brak stanowią ważny element rozwoju dzieci i młodzieży. Trudności adaptacyjne zarówno dotyczące wymagań szkolnych, jak i w zakresie kontaktów społecznych generują silny stres i kryzysy rozwojowe, a przeciągające się zmaganie $\mathrm{z}$ nimi może doprowadzić do pojawienia się syndromu wypalenia szkolnego i rezygnacji z dalszej edukacji (Tomaszek, 2015). Przedstawiony model zaangażowania ucznia $\mathrm{w}$ aktywności szkolne stosunkowo dobrze uwzględnia perspektywę mikrosystemu, w którym rozwija się dziecko. Postulaty J. Appleton i współpracowników (2008) wynikające z analizy wyników badań empirycznych wskazują, że istotnym aspektem pracy edukacyjnej z dziećmi i młodzieżą jest kształ- towanie ich autonomii, a nie jedynie stawianie wymagań. W kontekście wzmacniania zaangażowania uczniów ważne staje się promowanie oddziaływań prewencyjnych, które nakierowane są na kształtowanie bliskich więzi w środowisku szkolnym i rodzinnym. Relacje interpersonalne w środowisku rodzinnym, rówieśniczym, ale również w wymiarze nauczyciel-uczeń nierzadko mają decydujące znaczenie dla całego dalszego życia człowieka (Obuchowska, 2005). Jednocześnie obecnie realizowanie zadań wychowawczych i wspierających rozwój staje się coraz trudniejsze, gdyż najczęściej spotykaną formą spędzania czasu przez dzieci i młodzież jest aktywność, w której marginalizuje się sferę osobistych kontaktów na rzecz dominacji kontaktów wirtualnych i bezosobowych.

\section{BIBLIOGRAFIA}

Ang R.P., Huan V.S., Teng Chan W., Cheong S.A., Leaw J.N. (2015), The Role of Delinquency, Proactive Aggression, Psychopathy and Behavioral School Engagement in Reported Youth Gang Membership. Journal of Adolescence, 41, 148-156.

Appleton J.J., Christenson S.L., Furlong M.J. (2008), Student Engagement with School: Critical Conceptual and Methodological Issues of the Construct. Psychology in the Schools, 45(5), 369-386.

Appleton J.J., Christenson S.L., Kim D., Reschly A. (2006), Measuring Cognitive and Psychological Engagement: Validation of the Student Engagement Instrument. Journal of School Psychology, 44, 427-445.

Archambault I., Janosz M., Fallu J.-S., Pagani L.S. (2009), Student Engagement and its Relationship with Early High School Dropout. Journal of Adolescence, 32, 651-670.

Archambault I., Pagani L.S., Fitzpatrick C. (2013), Transactional Associations between Classroom Engagement and Relations with Teachers from First Through Fourth Grade. Learning and Instruction, 23, 1-9.

Assor A., Kaplan H., Kanat-Maymon Y., Roth G. (2005), Directly Controlling Teacher Behaviors as Predictors of Poor Motivation and Engagement in Girls and Boys: The Role of Anger and Anxiety. Learning and Instruction, 15, 397-413.

Astin A.W. (1984), Student Involvement: A Developmental Theory for Higher Education. Journal of College Student Personnel, 25, 297-308.

Aud S., Hussar W., Johnson F., Kena G., Roth E., Manning E. i in. (2012), The Condition of Education 2012 (NCES 2010-028). Washington, DC: National Center for Education Statistics, Institute of Education Sciences, U.S. Department of Education, http://nces.ed.gov/pubsearch.

Austin G., Benard B. (2007), The State Data System to Assess Learning Barriers, Supports, and Engagement: Implications for School Reform Efforts. Sacramento, CA: California Education Policy Convening.

Awang-Hashim R., Kaur A., Noman M. (2015), The Interplay of Socio-Psychological Factors on School Engagement Among Early Adolescents. Journal of Adolescence, 45, 214-224.

Baker J.A., Dilly L.J., Aupperlee J.L., Patil S.A. (2003), The Developmental Context of School Satisfaction: School as Psychologically Healthy Environments. School Psychology Quarterly, 2, 206-221.

Benavides L. (2014), Spiritual Journey from Childhood to Adolescence: Pathways to Strength and Healing. Journal of Religion \& Spirituality in Social Work: Social Thought, 33, 201-217.

Bronfenbrenner U. (1993), Ecological Models of Human Development. W: M. Gauvain, M. Cole (eds.), Readings on the Development of Children, 37-43. New York: Freeman. 
Bronnfenbrenner U., Morris P.A. (2006), The Bioecological Model of Human Development. W: W. Damon, R.M. Lerner (eds.), Handbook of Child Psychology: Theoretical Model of Human Development, 793-828. New York: John Wiley.

Brophy J. (1983), Conceptualizing Student Motivation. Educational Psychologist, 18, 200-215.

Burns J., Collin P., Blanchard M., De-Freitas N., Lloyd S. (2008), Preventing Youth Disengagement and Promoting Engagement. Australian Research Alliance for Children \& Youth.

Christenson S.L., Anderson A.R. (2002), Commentary: The Centrality of the Learning Context for Students' Academic Enabler Skills. School Psychology Review, 31, 3, 378-393.

Coates H. (2007), A Model of Online and General Campus-Based Student Engagement. Assessment and Evaluation in Higher Education, 32(2), 121-141.

Connell J.P., Wellborn J.G. (1991), Competence, Autonomy, and Relatedness: A Motivational Analysis of Self-System Processes. W: M.R. Gunnar, L.A. Sroufe (eds.), Self Processes and Development, 43-77. Hillsdale, New York: Lawrence Erlbaum.

Cornell D., Shukla K., Konold T. (2016), Authoritative School Elimate and Student Academic Engagement, Grades, and Aspirations in Middle and High Schools, AERA Open, 2, 2, 1-18.

Dolzan M., Sartori R., Charkhabi M., De Paola F. (2015), The Effect of School Engagement on Health Risk Behaviours among High School Students: Testing the Mediating Role of Self-Efficacy. Procedia - Social and Behavioral Sciences, 205, 608-613.

Fall A.M., Roberts G. (2012), High School Dropouts: Interactions Between Social Context, Self-Perceptions, School Engagement, and Student Dropout. Journal of Adolescence, 35, 787-798.

Fernández-Zabala A., Goñi E., Camino I., Zulaika L.M. (2015), Family and School Context in School Engagement. European Journal of Education and Psychology, 1-9.

Finn J.D. (1989), Withdrawing from School. Review of Educational Research, 59, 117-42.

Fredricks J., Blumenfeld P.C., Paris A.H. (2004), School Engagement: Potential of the Concept, State of the Evidence. Review of Educational Research, 74, 1, 59-109.

Fredricks J., McColskey W., Meli J., Mordica J., Mooney K. (2011), Measuring Student Engagement in Upper Elementary through High School: A Description of 21 Instruments. Greensboro: Institute of Education Science, Issues and Answers Report, REL 2011-No. 098.

Furlong M. J., Whipple A.D., St. Jean G., Simental J., Soliz A., Punthuna S. (2003), Multiple Contexts of School Engagement: Moving Toward a Unifying Framework for Educational Research and Practice. The California School Psychologist, 8, 99-113.

Gallup Inc. (2013), U.S. Overall: Gallup Student Poll Results, 1-6.

Gallup Inc. (2015-2016), U.S. Overall: Gallup Student Poll Results - Summary, 1-2.

Gulla B., Tucholska K. (2007), Psychologia pozytywna: cele naukowo-badawcze i aplikacyjne oraz sposób ich realizacji. Studia z psychologii w KUL, 14, 133-152.

Hallberg U.E., Schaufeli W.B. (2006), „Same Same” but Different? Can Work Engagement be Discriminated from Job Involvement and Organizational Commitment. European Psychologist, 11(2), 119-127.

Havermans N., Botterman S., Matthijs K. (2014), Family Resources as Mediators in the Relation Between Divorce and Children's School Engagement. The Social Science Journal, 51, 564-579.

Hazel C.E., Vazirabadi G.E., Albanes J., Gallagher J. (2014), Evidence of Convergent and Discriminant Validity of the Student School Engagement Measure. Psychological Assessment, 26, 3, 806-814.

Hazel C.E., Vazirabadi G.E., Gallagher J. (2013), Measuring Aspirations, Belonging, and Productivity in Secondary Students: Validation of the Student School Engagement Measure. Psychology in the Schools, 0, 1-16.

Kahn W.A. (1990), Psychological Conditions of Personal Engagement and Disengagement of Work. Academy of Management Journal, 33(4), 692-724.

Kwiatek P., Wilczewska K. (2015), Czym jest, a czym nie jest psychologia pozytywna? Poszukiwanie paradygmatu. Seminare, 36, 4, 135-145.

Lam S., Jimerson S., Wong B.P.H., Kikas E., Shin H., Veiga F.H., Hatzichristou C., Polychroni F., Cefai C., Negovan V., Stanculescu E., Yang H., Liu Y., Basnett J., Duck R., Farrell P., Nelson B., Zollneritsch J. (2014), Understanding and Measuring Student Engagement in School: The Results of an International Study from 12 Countries. School Psychology Quarterly, 29(2), 213-232. 
Libbey H. (2004), Measuring Student Relationship to School: Attachment, Bonding, Connectedness, and Engagement. Journal of School Health, 74(7), 274-283.

Macey W.H., Schneider B. (2008), The Meaning of Employee Engagement. Industrial and Organizational Psychology, 1, 3-30.

Marks H.M. (2000), Student Engagement in Instructional Activity: Patterns in Elementary, Middle and High School Years. American Educational Research Journal, 37, 153-184.

Martin A.J., Malmberg L.-E., Liem G.D. (2010), Multilevel Motivation and Engagement: Assessing Construct Validity Across Students and Schools. Educational and Psychological Measurement, 70, 973-989.

Martin A.J., Papworth B., Ginns P., Malmberg L.-E., Collie R.J., Calvo R.A. (2015), Real-Time Motivation and Engagement During a Month at School: Every Moment of Every Day for Every Student Matter, Learning and Individual Differences 38, 26-35.

Mosher R., McGowan B. (1985), Assessing Student Engagement in Secondary Schools: Alternative Conceptions, Strategies of Assessing, and Instruments. University of Wisconsin, Research and Development Center (ERIC Document Reproduction Service No. ED 272812).

Natriello G. (1984), Problems in the Evaluation of Students and Student from Secondary Schools. Journal of Research and Development in Education, 17, 14-24.

Newmann F.M. (1992), Student Engagement and Achievement in American Secondary Schools. Teacher College Press.

Obuchowska I. (2005), Adolescencja. W: B. Harwas-Napierała, J. Trempała (red.), Psychologia rozwoju człowieka. Charakterystyka okresów życia człowieka, 163-199. Warszawa: PWN.

O’Toole N., Due C. (2015), School Engagement for Academically At-Risk Students: A Participatory Research Project. Australian Educational Research, 42, 1-17.

Ouweneel E., Le Blanc P., Schaufeli W. (2011), Flourishing Students: A Longitudinal Study on Positive Emotions, Personal Resources, and Study Engagement. Journal of Positive Psychology, 6, 142-153.

Pietarinen J., Soini T., Pyhältö K. (2014), Students' Emotional and Cognitive Engagement as the Determinants of Well-Being and Achievement in School, International Journal of Educational Research, 67, 40-51.

Ramey H.R., Rose-Krasnor L., Busseri M.A., Gadbois S., Bowker A., Findlay L. (2015), Measuring Psychological Engagement in Youth Activity Involvement. Journal of Adolescence, 45, 237-249.

Reeve J., Tseng Ch.-M. (2011), Agency as a Fourth Aspect of Students' Engagement During Learning Activities, Contemporary Educational Psychology, 36, 257-267.

Rumberger R.W., Larson K.A. (1998), Student Mobility and the Increased Risk of High School Dropout. American Journal of Education, 107, 1-35.

Russell V.J., Ainley M., Frydenberg E. (2005), Student Motivation and Engagement. Schooling Issues Digest, $2,1-11$.

Salmela-Aro K., Savolainen H., Holopainen L. (2009), Depressive Symptoms and School Burnout During Adolescence: Evidence from Two Cross-Lagged Longitudinal Studies. Journal of Youth Adolescence, 38, $1316-1327$.

Salmela-Aro K., Upadyaya K. (2014), School Burnout and Engagement in the Context of Demands - Resources Model. British Journal of Educational Psychology, 84, 137-151.

Schaufeli W.B., Martínez I.M., Pinto A.M., Salanova M., Bakker A.B. (2002b), Burnout and Engagement in University Students: A Cross-National Study. Journal of Cross-Cultural Psychology, 33, 464-481.

Schaufeli W.B., Salanova M., González-Romá V., Bakker A.B. (2002a), The Measurement of Engagement and Burnout: A Two Sample Confirmatory Factor Analytic-Approach. Journal of Happiness Studies, 3(1), 71-92.

Skinner E.A., Belmont M.J. (1993), Motivation in the Classroom: Reciprocal Effects of Teacher Behavior and Student Engagement Across the School Year. Journal of Educational Psychology, 85(4), 571-581.

Skinner E.A., Furrer C., Marchand G., Kindermann T. (2008), Engagement and Disaffection in the Classroom: Part of a Larger Motivational Dynamic?. Journal of Educational Psychology, 100, 765-781.

Smiley W., Anderson R. (2011), Measuring Student's Cognitive Engagement on Assessment Tests: A Confirmatory Factor Analysis of the Short Form of the Cognitive Engagement Scale. Research of Practice Assessment, 6, 17-28. 
Szabowska-Walaszczyk A. (2010), Zaangażowanie w pracy i organizacji - przegląd problematyki i narzędzi pomiaru. W: A.M. Zawadzka (red.), Psychologia zarządzania w organizacji, 143-169. Warszawa: PWN.

Tomaszek K. (2015), Wypalenie szkolne - nowe wyzwanie dla nauczycieli. W: S. Kowal (red.), Nauczyciel: między etosem a presją rzeczywistości. Teoria, praktyka, codzienność, 1, 105-118. Kraków: Wydawnictwo Uniwersytetu Pedagogicznego.

Trowler V. (2010), Student Engagement Literature Review. Lancaster University: The Higher Education Academy. Department of Educational Research.

Tucholska S. (2012), Zaangażowanie szkolne uczniów i jego korelaty. W: I. Ulfik-Jaworska, A. Gała (red.), Dalej $w$ tę sama stronę, 271-281. Lublin: Wydawnictwo KUL.

Veiga F.H. (2016), Assessing Student Engagement in School: Development and Validation of a Four-Dimensional Scale. Procedia - Social and Behavioral Sciences, 217, 813-819.

Veiga F.H., Reeve J., Wentzel K., Robu V. (2014), Assessing Students' Engagement: A Review of Instruments with Psychometric Qualities. International Perspectives of Psychology and Education, 38-57.

Wang M.T., Chow A., Hofkens T., Salmela-Aro K. (2015), The Trajectories of Student Emotional Engagement and School Burnout with Academic and Psychological Development: Findings from Finnish Adolescents. Learning and Instruction, 36, 57-65.

Wang M.T., Peck S.C. (2013), Adolescent Educational Success and Mental Health Vary Across School Engagement Profiles. Developmental Psychology, 49, 1266-1276.

Wilson S.J., Tanner-Smith E.E., Lipsey M.W., Steinka-Fry K., Morrison J. (2011), Dropout Prevention and Intervention Programs: Effects on School Completion and Dropout Among School Aged Children and Youth. Oslo: Campbell Systematic Reviews. 